\title{
Milton, Satan, and the Sophists
}

\author{
DOUGLAS WURTELE
}

First in your sermons use your Logick \& then your Rhetorick. Rhetorick without Logick is like a tree with leaves \& blossomes, but no roote; yet I confess more are taken with Rhetorick then Logick, because they are catch'd with a free expression, when they understand not reason.

John Selden: Table Talk ${ }^{1}$

The poet Milton held in high regard the learning of John Selden, "our distinguished countryman," 2 whose views on preaching were far from being incompatible with his own, radically different though their views on marriage and divorce. Milton's equally strong interest in the proper uses of rhetoric and logic was matched by his lifelong contempt for their misuse by the practitioners of sophistry. One way of understanding Milton's complex treatment of Satan, indeed, is to regard the Prince of Darkness as an evilly inclined orator skilled in sophistic rhetoric and logic, a kind of demonic prototype for the deceptive sophists of Milton's own day. Further, one reason why the poet was able to depict so effectively in Paradise Lost the methods which he castigates so severely in his opponents' practice is that he himself underwent a thorough, if somewhat reluctant, training in the same techniques.

The educational system at Cambridge in Milton's time rested in large part on the medieval model. ${ }^{3}$ Rhetoric, logic, and metaphysics occupied the main share of study for the B.A., and the disputation method continued to serve as evidence of the student's mastery of his training. E.M.W. Tillyard gives an account of the objections raised against a certain disputant on the grounds that "he railed against school divinity, whereas King James and King Charles commanded young students in divinity to begin with Lombard and Aquinas." "4 That Milton detested the system is equally well known. At an early stage he voiced his feelings about scholastic philosophy in the school exercise known as Prolusion III. It is significant that in his "diatribe against scholastic philosophy in general" this future opponent of sophistical deceivers has "cogently 
employed the techniques of the very system which he decried." 5 In this exercise Milton's account of the despised studies is indeed highly rhetorical; yet the lavish imagery succeeds in its purpose. Behind the extravagant posing gleams his scorn for a system designed to produce sophists:

Believe me, my learned friends, when I go through these empty quibbles as I often must, against my will, it seems to me as if I were forcing my way through rough and rocky wastes, desolate wildernesses, and precipitous mountain gorges. And so it is not likely that the dainty and elegant Muses preside over these ragged and tattered studies, or consent to be the patrons of their maudlin partisans; and I cannot believe that there was ever a place for them on Parnassus unless it were some waste corner at the very foot of the mountain, some spot with naught to commend it, tangled and matted with thorns and brambles, overgrown with thistles and nettles. $(C P, 1,243)^{6}$

In Prolusion VII, he again employs harsh natural imagery: "what about logic?... Its teachers are not like men at all, but like finches which live on thorns and thistles." As for metaphysics, "it is, I say, not an Art at all, but a sinister rock, a Lernian bog of fallacies, devised to cause shipwreck and pestilence" (CP, I, 300-1). ${ }^{7}$ A decade later, in the Of Education pamphlet (1644), addressed to Samuel Hartlib, he expresses his disgust in English metaphors strikingly similar to his Latin ones. Commonly set before "our choisest and hopefullest wits" as "all the food and entertainment of their tenderest and most docible age" is, he declares, an "asinine feast of sowthistles and brambles" (CP, II, 377).

In these examples Milton's metaphorical language reaches beyond the derisive to the allusive. The ominous tone of the nature imagery-rocks, wastes, desolation, wilderness, gloom, tangles - foreshadows the sombre dwelling place of the angelic intelligences who have been deluded by the Arch-enemy's sophistries. Viewing the "dismal Situation waste and wilde," 8 Satan describes it to Beelzebub as a "dreary Plain, forlorn and wilde,/The seat of desolation" (I. 180-81). Later, while the "Adversary of God and Man" (II. 629) is winging his way to the gates of Hell, the fallen angels explore their rocky wasteland, "a Region dolorous, ... Created evil, for evil only good" (II. 619-23), the physical description of which recalls the satirically depicted wasteland of scholastic studies.

It is against the background of Milton's abiding distrust for such studies that his abhorrence of sophisters should be set. His work abounds in caustic references to their deceitful practice. In the Reason of ChurchGovernment (1642) Milton strikes at opponents who resort to name calling: "And whom ye could not move by sophisticall arguing, them you thinke to confute by scandalous misnaming" ( $C P, \mathrm{I}, 788)$. In Milton's polemical campaigns lies and slanders are frequently identified with the vices of sophistry. The same work also makes a scornful 
distinction between false learning, essentially rhetoric-based, and the "true lore of religion or moral vertue" $(C P, \mathrm{I}, 854)$ and, as well, offers an occasion to denounce the university training already attacked in the academic disputations. Here he has to account for the fact that "studious men" of "honest and ingenuous natures" have publicly defended prelatry. These men, he explains, have been deluded by "scragged and thorny lectures of monkish and miserable sophistry" and are therefore hindered from acquiring true understanding (CP, I, 854). Milton is aware of the threat that the sophist's skill in deceptive rhetoric and fallacious logic presents to virtuous men who undergo this kind of training. So exposed, they may come to admire "prelatically addicted" speakers who have been "slightly train'd up in a kind of hypocritical and hackny cours of literature to get their living by, and dazle the ignorant" ( $C P, \mathrm{I}, 854)$. From the repugnance of his student days, through the vituperation of the pamphlet wars, and finally with the portrayal of Satan, Milton consistently warns of the seductiveness concealed in the sophist's verbal trickery.

A similar warning concludes Areopagitica (1644), the Stationers being accused of logical deceit in their "Sophisms and Elenchs of marchandize" (CP, II, 570). By these terms Milton is charging them with the use of "sophistical arguments to establish false propositions and elenchical arguments (in the sense of false refutations) to defend themselves against true charges or sound objections."9 Commenting on an entry in Milton's Commonplace Book from Basil the Great's eighth homily on Genesis, in which sophists are compared to night owls, Ruth Mohl draws attention to Milton's frequent references elsewhere to sophists and sophistries. ${ }^{10}$ As she points out, Milton abhors those "who obscure vital truths by their concern with the petty and superficial." Far worse than the obscuring of vital truths, however, is the active promulgation of pernicious untruths. Sophistry and lies, then, are the two sides of Satan's false coin, a point that Milton makes explicit in his recension of Petrus Ramus' Artis Logicae Plenior Institutio. There he equates falsity with sophistry by describing a certain type of logic as "in falso sive sophistico" (II, ix). ${ }^{11}$

A long tradition of distrust for sophistry, extending from Plato and Aristotle through the more recent authority of John of Salisbury, lay behind the abhorrence expressed by Milton and men of like mind. ${ }^{12}$ Few, however, have expressed that abhorrence so forcefully as did Milton the polemicist and poet. For a very good reason, practitioners of sophistry are seen to be fundamentally different from the true orator, beneficial to society. For Milton that man's essential quality comes close to Quintilian's ethical requirement for the perfect orator: "The first essential for such an one is that he should be a good man." ${ }^{13}$ This dic- 
tum is echoed in an assertion in Milton's fifth and final antiprelatical pamphlet, An Apology Against a Pamphlet (1642): "So that how he should be truly eloquent who is not withall a good man, I see not" ( $C P$, I, 874). ${ }^{14}$ There are strains that confirm this view in Of Education (1644); and as late as Pro Se Defensio (1655) a similar attitude, couched in negative terms, persists. Here Milton argues that if at Athens "the laws of the heathens" could decree that "no orator known for the baseness of his life... should have the right to speak on public matters," then surely it is the more shameful that his foe, Alexander More, "a fornicator and adulterer," should have the "pernicious" right to preach to Christians ( $C P, \mathrm{IV}, 761-62)$. In short, the good man is to true oratory as the bad one is to sophistry. This principle helps explain the seemingly ad hominem tone of Milton's attacks on his foes: it is relevant, indeed essential, to his purpose that their moral baseness be exposed.

It is sometimes thought that in later years Milton grew to distrust even the right use of oratory extolled in the early works. The apparent rejection of oratory by Christ ( $P R, I V .356-60)$ seems on the surface to be consistent with a supposed movement by Milton "away from his early liberal thought." 15 Even if this were so, Milton never altered his views on the "corrupting effects of false rhetoric," 16 but in any case the context of Christ's disavowal has to be considered. What is really being condemned here is false oratory, for it is after all Satan, the archetypal sophist, whose arguments are being refuted. In comparison with Holy Writ, all oratory, as Satan argues for it, has to be rejected, for Satan can make no distinction between true and false oratory. Moreover, Milton implicitly gives approval to the practice of the true orator in his exhibition of Abdiel's verbal conflict with Satan (PL, V. 809-907, VI. 114-188). His views on oratory, then, may not really be inconsistent. From first to last he recognizes the value of good oratory and the dangers of bad oratory; and the distinction seems to lie in the kind of logic and rhetoric professed, to say nothing of the moral state of the orator. What Milton thought of the old-style methods taught at Cambridge we have seen. But certainly he held in respect the new school of logic and rhetoric initiated by Petrus Ramus and his followers, whose aims met the vital test of sincerity. In his Life of Petrus Ramus, appended to the recension of the Logica, Milton speaks approvingly of an oration delivered by Ramus that recommended "the union of the studies of philosophy and eloquence" (CE, XI, 501-3), an important statement because it shows that Milton always maintained a distinction between true oratory and false. How far he endorsed the Puritan orators' veneration for Ramist methods and principles is not the issue here; he has been called a "Ramist of sorts." 17 The important thing is that Ramus held the subtleties of the sophists and the "frivolity and incoherence" of the 
old style scholastic education in as great contempt as did Milton. ${ }^{18}$ Equally important is the opposition of "Aristotelians" like Hooker and Laud to the Cambridge Puritan Ramists. ${ }^{19}$ Given Milton's views on church government, this opposition to Ramist attitudes on logic and rhetoric in sermon oratory would be tantamount to a coupling of sophistry with prelatry. Sophistry, then, whether sermonistic or forensic, can be identified with enmity to that divine will which Milton believed he apprehended and which had appointed him to use his pen in its furtherance. In the great polemical tracts of the immediately postregicide period, then, it is not surprising to find an abundance of examples that equate sophistical oratory and pamphleteering with falsehood incarnate. ${ }^{20}$

Among the numerous terms of odium which Milton applies to his two main antagonists, Claudius Salmasius and Alexander More, that of "sophist" and its variants occurs with notable frequency. In the Defensio Milton early announces his intention of refuting the "ill-tempered lies" of Salmasius, the "barbarous rhetorician" (p. 306), whose only accomplishment is to "blabber out before strangers some empty speeches and other nonsense for a high price" (p. 320). Just or unjust, this coupling of vacuity and cupidity echoes Aristotle's definition of the sophist's practice as "a money-making art which trades on apparent wisdom." 21 A similar imputation of mercenary greed in Satan's case may be in Milton's mind when the archetypal sophist is likened to a "Thief bent to unhoord the cash" (IV. 188). As to Salmasius, the imputation is made scornfully explicit in Milton's later description of this "prattling orator" (p. 323) as a "wandering hireling buffoon" (p. 487). But the comment that links this "raving sophist" (p. 535) most closely to Satan's depredations is Milton's ironically expressed hope that the Dutch youths under Salmasius' tutelage will avoid falling from freedom into slavery, being subject as they are to this man's "lying sophistry" (p. 430). The sardonic comment recalls Satan's cry for "Servilitie with freedom to contend" (VI. 169) in his perverse equating of loyalty with slavery and rebellion with liberty.

Placed alongside these accusations of sophistry against Salmasius, that "Man of evil" (p. 498), ${ }^{22}$ the abuse heaped on Alexander More, the supposed author of the reply to Milton's attack, strikes one as even more pungent. Accused (wrongly) in Defensio Secunda of writing the Regii Sanguinis Clamor, the "petty rhetorician" (p. 648) is further attacked, and more remorselessly, in Pro Se as a "wandering sophist" and an "infamous sophist" (pp. 765, 793); he is told in the same work that the very title of the tract which he did in fact compose to deny authorship of Clamor, namely, Fides Publica, is either "sophistical or ienseless" (p. 721). The accusation that this sophist is not only an 
unscrupulous deceiver but also a mercenary hireling is repeated when Milton asks if More supposes that by this "septenary din and fortuitous doctrine, like some cyclic poet, who recited when asked, or some sophist" he has fulfilled his office of pastor (p. 821). Milton then employs the device of guilt by association by likening More's arguments to the "devil's rhetoric" and linking his opponent both to the Emperor Julian and to the fallen Lucifer in the epithet "apostate" (p. 823).

By imputing to his foes the crime of deliberate sophistical deceit in these direct terms of abuse, Milton is trying to equate their malice with that of the Arch-foe himself. This he does not only by directly identifying them as sophisters, but also by directly unmasking their evasions and fallacies. In the culmination of his lifelong campaign against sophistry, Milton will expose, in the speeches ascribed to Satan, the primordial roots of fallacious logic and deceptive eloquence. Meanwhile, now in the "sun, and dust, and field of battle" (p. 795), Milton, perhaps recalling here the spirit of his own Areopagitica, relentlessly pursues these latter-day adversaries of truth, Salmasius and More. Significantly, then, the abusive language with which he peppers the tracts yields a great many verbal overtones that resonate with descriptions of Satan later to be portrayed in the epics. These resonances include specific epithets of opprobrium, metaphorical descriptions similar to those applied to Satan, and a number of associative allusions to diabolical evil.

In Pro Se Milton denounces More as "basest adversary" (p. 699), who, by denying the authorship of Clamor, practises "fraud and deceit" (p. 714). Satan is frequently called "adversary" and, in Adam's words, "contriv'd/. . .deceit" (X. 1034-35). Satan himself promises to perform "fraud" (I. 646) and is called the "Artificer of fraud" (IV. 121). As well, Milton more than once accuses More of being a liar. In Defensio Secunda he speaks of the "lies our enemy has told" (p. 558) and in Pro Se calls him a "lying charlatan" (p. 723). Gabriel describes Satan, who also is frequently called "enemy," as a "lyar trac't" (IV. 949); and earlier it is prophesied that the greater part of mankind will be corrupted by his "falsities and lyes" (I. 367). God the Father warns that man lies in danger of Satan's "deceit and lies" (V. 243). With constant iteration Milton accuses Salmasius and More of "audacity" and "impudence" or of being an "audacious foe" or "impudent" (e.g., Defensio, pp.483, 498; Secunda, p. 549; Pro $S e$, pp. 722, 732, 736, 805). Satan is very often called "foe," as in "foe to God and Man" (IV. 749), and is described as ascending "Audacious" (II. 931) and branded as "impudent" (PR, IV. 154). More is told in Pro Se that he acts "impudently and maliciously" (p. 822), and Satan, too, is called the "malicious Foe" (IX. 253). Not only does Milton accuse his earthly adversary of acting maliciously; in Defensio Secunda he also points to the "living image of the falseness and malice" 
that dwell within him (p. 584). ${ }^{23}$ One recalls the "false Arch-Angel" (V. 694), when, having "improv'd/In meditated fraud and malice" (IX. 55 ), he returns to Eden where, before long, Adam will caution Eve unavailingly not to disregard the enemy's "malice and false guile" (IX. 306).

These are only a few of the direct epithets of contempt with which Milton couples his human foes and man's archetypal foe alike. Salmasius is a "parasite" (Defensio, p. 469), as Christ describes Satan (PR, I. 452); he displays "slavish spite" (Defensio, p. 396), and Satan himself swears to repay "spite then with spite" (IX. 178) and later, "for very spight" (PR, IV. 12), persists in his tempting of Christ. Salmasius' argument is vilified as "blasphemous" (Defensio, p. 367), as is that of Satan in the rebuttal by Abdiel (V. 809). More is accused of committing "calumnies" and "vice" (Pro Se, pp. 736, 743); Satan, the original sophist, practises "calumnious Art/Of counterfeted truth" (V. 770-71), while Belial, his confederate, is "To vice industrious" (II. 116). More is accused by Milton of "impious action" (Pro Se, p. 805) and Satan of "impious obloquie" (V. 813) by Abdiel, who in many ways stands as Milton's personal spokesman in Paradise Lost.

These verbal resonances suggest that epithets of this kind, being associated in Milton's mind with the Father of Lies, naturally flow from his pen when he is castigating present-day liars. Then, when writing the epics, the terms of vilification used against his own adversaries recur in his descriptions of the primeval Adversary. Somewhat different from this procedure are the allusions where metaphorical rather than expletive language serves to enforce associations of a like nature. In richly suggestive metaphors Milton's foes are described as "churlish and corrupt" men who are directing at him "their venom and their darts" (Pro Se, p. 699). ${ }^{24}$ That these terms may have carried literally hellish overtones is suggested by the subsequent description by Milton of the gates of Hell, where Death shakes his dart at Satan (II. 672), and by the prophecy that Satan's own "fierie darts" will be quenched by a Comforter (XII. 492). Indeed, these darts are described as "spent" after his encounter with the Saviour ( $P R$, IV. 366). Earlier, crouching toad-like beside Eve, Satan tries to taint her "animal Spirits" by "inspiring venom" (IV. 80405). Milton sardonically describes Alexander More's face as "venerable with furrows" (Pro Se, p. 749), a phrase reminiscent of the equally sardonic picture of the posturing Satan, whose face "Deep scars of Thunder had intrencht" (I. 600). Salmasius is called a "sainted Wolf" (Defensio, p. 380) ${ }^{25}$ and More a "preaching wolf" (Pro Se, p. 761). Aptly descriptive of Satan as the "prowling Wolfe" is the epic simile dealing with his first reconnaissance of the Garden (IV. 183). Milton, nearing the end of his attack on More's subject matter, declares that "star-struck by its very foulness" More "falls dumb" (Pro Se, p. 775). 
One thinks of Satan, "to shameful silence brought" by "repulse upon repulse" ( $P R$, IV. 21-22). The discourse of Salmasius, that "rascal houseborn slave," grows "swollen and turbid" (Defensio, p.334); Satan, alarmed by the Angelic Squadron, "dilated stood" (IV. 986) and, rejected by the Son, grows "swoln with rage" (PR, IV. 499). Even more suggestive of scenes later to depict the "arch-fellon" (IV. 179) is the gibe levelled at More, compared with some "odious felon," who is asked, "Whither shall you turn, wretch?" (Pro Se, p. 775). The phrase can hardly fail to recall Satan's despairing cry, "Which way shall I flie?" (IV. 73). Like Satan, More, once given to "boasting and bragging" (Pro Se, p. 705), now cannot escape his own despair. "In vain, poor worthless man," Milton declares to the putatively fleeing More, "for you fly with yourself, you follow yourself" (Pro Se, p. 776). ${ }^{26}$ Satan, regretting "that boast so vaine" (IV. 87), likewise realizes "Which way I flie is Hell; myself am Hell" (IV. 75). An even more direct allusion to Hell comes when Milton, referring to More's supposed ability to "stir up hornets,'" disdainfully comments, "You would almost declare him another Beelzebub, save only that he stirred up flies" (Pro Se, p. 818). ${ }^{27}$

These associative connections between Milton's sophistical foes and the Arch-sophist himself are accompanied by denunciations bearing unmistakably grimmer overtones. The name "hypocrite" is very frequently levelled at More, once, indeed, even juxtaposed with the suitable epithet, "diabolical" (Pro Se, p. 751). When Satan reminds the Son that God "Suffers the Hypocrite or Atheous Priest" to handle "holy things" (PR, I. 487-89), his sophistry is, of course, a perverse vindication of his own hypocrisy. ${ }^{28}$ The touching of sacred things by More's defiling hands is specified frequently by the relentless Milton in Defensio Secunda as proof of the wretched man's hypocrisy. ${ }^{29}$ Nor does Salmasius, that " 'great' rhetorician" (p. 636), escape the charge: he is called a "hypocritical atheist" (p. 498). These terms resonate with some of the most memorable denunciations of Satan in Paradise Lost. There the Arch-foe is called a "sly hypocrite" (IV. 957) and his following an "Atheist crew" (VI. 370); he is the "Author of evil" (VI. 262) and simply, at the end, the "Evil one" (IX. 463). In Paradise Regained he is named for all time as "That Evil one, Satan for ever damn'd" (IV. 194). There is, consequently, grim appropriateness in Milton's designation of More as "minister of the devil" (p. 631).

Descriptions such as these should not be regarded merely as conventional terms of abuse in an ad hominem exchange of merely passing significance, but rather as precise referents designed to connect the Author of evil with those who, at all times and in all places, do his work by fraud and deceit. It is by no casual, name-calling impulse that Milton makes his enemies share with Satan, rhetoricians all, the most damning 
title available, that of apostate. This term Milton applies in Pro Se to the author of the Fides Publica (p. 823), but it is Salmasius, the more redoubtable adversary, against whom the charge of apostasy is laid with ferocious iteration. In the Defensio it occurs over and over. Salmasius had, Milton avers, earlier supported the Reformation principle of antiprelacy, but now, in his Defensio Regia, he appears to favour the retention of bishops. "What apostate ever betrayed the faith so foully and so wickedly?" Milton demands, further associating his foe with the Archfoe by calling him a "lost soul" (p. 499). On the same issue he condemns Salmasius for "madness, impiety, and apostasy" and declares, in suggestive juxtaposition with his foe's own charge that Milton's side " "sprang from the darkness of Hell," " that Salmasius himself is an "empty lying hired slanderer and apostate" (p. 515). This concentration of epithets sums up, at one blow, all of Milton's hatred for the particular characteristics of sophistry and devilry together. But his scorn cuts deeper yet. Salmasius is both "an apostate and a devil" and, what is more, even King Charles knew this when awarding him a purse of gold (p. 534). There could have been no hesitation in Milton's mind in forming such an association. Satan is described as the "Apostate Angel" (I. 125), a term to be applied to him and his followers, demonic and human, many times in the epics as it is applied to Milton's foes many times in the polemics. $^{30}$

As if, however, this direct association with Satan's principal crime were not enough by way of indictment, there remains the concomitant of unforgivable sin, despair. As Milton well knew, the "lost soul," as Salmasius is also called, who suffers the greatest pains in Hell is Judas Iscariot. ${ }^{31}$ That very name is as synonymous with despair as it is with treachery. In the Defensio Secunda the indictment against More could hardly be more explicit. To be, as More is, an atheist, defiler, brute, and slanderer, "what else is this but to be a genuine Iscariot, a veritable devil?" (p. 637) ${ }^{32}$ The expostulation is no mere piece of rhetoric. Linked in time, the "lying sophistry" of Salmasius and that practised by Satan may differ in degree but not in kind. By allusive reference, the link between angelic and human devilry is forged tightly. In the Defensio Milton promises the apostate Salmasius that he will "yield to despair and, cursed by all good men, end that life which suits you so well by hanging yourself" before he will live to see the death of the regicides (p. 450). In the closing peroration he reaffirms the association with Judas by warning Salmasius that "like that model of yours, you will be impelled more by desperation than repentance to hang yourself on that ill-omened tree through disgust with yourself, and fall to pieces with a crash, sending ahead your treacherous lying conscience...to its destined place of punishment!" (p. 534). ${ }^{33}$ The association is, again, no mere 
piece of name-calling. As Milton is at pains to show, the despair that racked Judas and will, in his view, soon rack Salmasius, had its birth, like Sin, within Satan himself. The apostate angel, "rackt with deep despare" (I. 126), cries that he cannot escape "infinite despaire" (IV. 74) and grows pale with the shifting passions of "ire, envie and despair" (IV. 115).

Now, after this ominous prophecy of the "prattling orator's" despairing end, Milton declares his task of exposing the "jealous rage" of this "raving sophist" (p. 535) to be complete. The associative links are made final. Despair and spite, envy and ire, jealousy and rage, apostasy and lies, all these Milton ascribes in equal measure to God's foes and his own, be they human or diabolical. Significantly, his indictment ends where it began, with the charge of sophistry. The poetic depictions of Satan, the Arch-sophist, like the prose attacks on sophistry in general and certain sophists in particular, have been composed in a state of intense but controlled anger and articulated by means of vivid yet deliberate imagery. Above the seemingly abusive, the superficially ad hominem, lies the Augustinian principle of employing against God's enemies their own rhetorical techniques. ${ }^{34}$

\section{Carleton University}

\section{Notes}

1 Table Talk of John Selden, ed. Sir Frederick Pollock for the Selden Society (London: Quaritch, 1927).

2 Milton so refers to Selden in the Defensio Secunda. See Complete Prose Works, ed. Don M. Wolfe et al. (New Haven and London: Yale University Press, 1949-73), IV, 625. All citations to translations of Milton's Latin prose works will be from this edition $(C P)$; the Latin version, where necessary, will be cited from the Columbia Edition $(C E)$ of The Works of John Milton, ed. Frank A. Patterson et al. (New York: Columbia University Press, 1931-40). For further information on Milton and Selden, see Ruth Mohl, ed. Commonplace Book, CP, I, 403, and see also $n .10$ below.

3 For a brief account see E.M.W. Tillyard, Studies in Milton (London: Chatto and Windus, 1951), pp. 113-36.

4 Tillyard, p. 120. See also, for Milton's experiences in the scholastic atmosphere of Cambridge, William Haller, The Rise of Puritanism (New York: Columbia University Press, 1938), pp. $297 \mathrm{ff}$.

5 For Milton's attack on scholastic disputations, see Prolusion III in CP, I, 240-48, trans. Phyllis B. Tillyard, ed. notes by Kathryn A. McEuen. For the above comment, see ed. intro., p. 240.

6 In the Latin version the closing phrase reads "nisi aliquem forte in imo colle angulum incultum, inamoeum, dumis \& spinis asperum, atque horridum, carduis, \& densâ urticâ coopertum...." (CE, X11, 162).

7 In the Latin version similar terms appear: "Quid Logica?... Non hic homines, sed plane Acanthides carduis \& spinis vescuntur.... [Metaphysicicam] non artem inquam plerumque, 
sed infames scopulos, sed Lernam quandam Sophismatum ad naufragium \& pestem ex cogitatam?" (CE, XII, 276). The Columbia translators prefer "sophisms" to Yale's "fallacies."

8 P.L., I. 60. All citations to P.L. and P.R. will be from CE; references to P.L. will be to book and line number only; those to P.R. will be so identified.

9 See comment by Ernest Sirluck, ed., Areopagitica, CP, II, 570, n. 310.

10 John Milton and his Commonplace Book (New York: Frederick Ungar, 1969), p. 82. Further information on John Selden will also be found here.

11 Ed. and trans. Allan H. Gilbert, $C E$, XI, 372-73. All citations will be to this edition of the work, referred to as Logica. Ramus' treatise was published in Milton's recension in 1672; see James Holly Hanford and James G. Taaffe, A Milton Handbook, 5th ed. (New York: Appleton Century Crofts, 1970), p. 296. See also Rosemond Tuve, Elizabethan and Metaphysical Imagery (1947; rpt. Chicago: University of Chicago Press, 1963), who points out that the sixteenth and seventeenth century both condemned "false or sophistical rhetoric" (p. 184).

12 See, for example, Plato, Sophist, 268C, and Aristotle, De Sophisticis elenchis, 165A 22. John of Salisbury, in Metalogicon, II. 3, II. 5, IV. 23, condemns with Miltonic vigour the worthlessness of sophistic art. At least three editions of this work appeared in the seventeenth century.

13 Institutio Oratoria, I, proem, 9, in Loeb Classics ed., trans. H.E. Butler (London: Heinemann, 1953), I, 9.

14 For the full title of this pamphlet and for an account of its occasion, see Frederick L. Taft, ed., in CP, I, 862-66. See also John S. Diekhoff, Milton's "Paradise Lost" (New York: Columbia University Press, 1946), pp. 15-16, for further comment on Milton's view that the poet as well as the orator should be a virtuous man.

15 G.F. Sensabaugh, "Milton's Learning," SP, 43 (1946), 262.

16 J.A. Wittreich, "Milton's Idea of the Orator," Milton Quarterly, 6 (1972), 38.

17 Walter J. Ong, Ramus, Method, and the Decay of Dialogue (Cambridge, Mass., Harvard University Press, 1958), p. 6. See also Tuve, p. 422, app. U, for a comment on the difficulty of trying to fit Milton's Ramist logic and his prose style "into the same box." Milton had felt the effect of Ramist influence on rhetoric and logic while still at St. Paul's School. See Donald L. Clark, John Milton at St. Paul's School (New York: Columbia University Press, 1948); also W. Fraser Mitchell, English Pulpit Oratory from Andrewes to Tillotson (London: SPCK, 1932). The affinity between Ramist logic and Puritanism has been further explored by John G. Rechtien, "The Visual Memory of William Perkins and the End of Theological Dialogue," JAAR, 45/1 (1977), 70-99.

18 See Perry Miller, The New England Mind: The Seventeenth Century (Cambridge, Mass., Harvard University Press, 1963), p. 123.

19 On the opposition of Hooker and the Laudians, see Miller, p. 118 and p. 142. On Ramist animadversions against the Aristotelians, see Ong, pp. 173-75.

20 For convenience, these are the pertinent titles and dates as listed in $C P$, IV, xii: Salmasius, Defensio Regia (1649); Milton, Pro Populo Anglicano Defensio [hereafter Defensio] (1651); Du Moulin, Regii Sanguinis Clamor [attributed at first to Alexander More by Milton] (1652); Milton, Defensio Secunda [hereafter so called] (1654); More, Fides Publica (1654); Milton, Pro Se Defensio [hereafter Pro Se] (1655). Page references only will be supplied, "CP, IV" being understood.

21 De Sophisticis elenchis, 171B 25, in Loeb Classics ed., trans. E.S. Forster (London: Heinemann, 1955), III, 63.

22 The phrase "O hominem impium, et Satanae tradendum" is rendered as "Man of evil, Satan's tool" in $C P, \mathrm{IV}, 498$, but in $C E$ as "A wicked wretch! who ought to be delivered over to Satan" (VII, 460).

23 "...habitantis in te improbitatis atque malitiae vivam imaginem" (CE, VIII, 62), where the first-named epithet is rendered "wickedness" rather than "falseness" as in CP; the sense of "dishonesty" seems more appropriate in context. A sampling of other Latin terms translated here as "impudent," "audacious," "maliciously," is as follows: "impudentiam," "audacissimum," "impudenter \& malitiosè." It must be remembered that the modern English equiva- 


\section{0 / Renaissance and Reformation}

lents may bear a weaker sense than the Latin and corresponding English words used by Milton in the treatises and the epics; "impudent," certainly, bears the more serious sense of "shamelessness."

24 ". . .importunissimus, corruptissimusque. . .in me omne virus et aculeos dirigit" $(C E, \mathrm{IX}, 4)$.

25 Milton, whose zest for sardonic punning is well demonstrated by his editors in $C P, I V$, is here playing on the name of Salmasius' estate in Burgundy, St. Loup.

26 A resemblance to P.L. IV. 75 is termed "unmistakable" by Kester Svendsen, ed., CP, IV, 766, n. 195.

27 The same editor's comment $(C P, I V, 818, \mathrm{n}, 302)$ is worth quoting in full: "The allusion develops naturally from the quotation preceding it; but it is also one of many tantalizing suggestions that Milton was at work on the Defences and Paradise Lost at the same time." While my own findings confirm this suggestion, I would add that simultaneous composition is not the only conclusion to be drawn from these resemblances. It is at least as likely that terms and allusions with overtones linking Satan to current practitioners of evil could continue to resonate in the poet's imagination at later stages in his writing career.

28 In Pro Se Milton constantly accuses More of being a "hypocrite" (e.g., pp. 733, 744, 751, 759); his Latin term is identical.

29 Milton accuses More of having "desecrated" by his touch the "sacred mysteries of religion" (p. 599), of being a "defiler of holy things" (p. 637), of having defiled "with incestuous hands the unperceived body of the Lord" (p. 654).

30 See P.L. I. 125, V. 852, VI. 100, VI. 172, VII. 44, VII. 610.

$31 \mathrm{Cf}$. Inferno, xxxiv. 50-60. Milton's term is "perditissime," rendered in CE, perhaps inadequately, as "villain" (VII, 460).

32 Donald A. Roberts, ed., Defensio Secunda, suggests that Milton, infuriated by the unfair slurs on John Bradshaw, for which More was deemed responsible, here reverts "to pure abuse, unrelieved by wit, satire, or rhetorical dexterity" (CP, IV, 637, n. 379). I would argue that this "abuse" may be more deliberate and controlled than that, forming part of a "guilt by association" plan to link Milton's (and God's) enemies with Satan.

33 Although Salmasius, who died in 1653 , before the Defensio Secunda was published, did not end his life Judas-fashion, Milton nevertheless asserted at the beginning of that work $(C P$, IV, 549) that his "audacious foe. . .fled, broken in spirit and reputation," a striking example of an orator's superlatio.

34 Milton's poetry exemplifies throughout the moral and aesthetic principles of St. Augustine's De Doctrina Christiana; see especially IV. ii. 